\title{
The proteolytic systems of ruminal microorganisms
}

\author{
RJ Wallace \\ Rowett Research Institute, Bucksburn, Aberdeen AB2 9SB, UK
}

Protein breakdown in the rumen is generally regarded as detrimental to the efficiency of ruminant nutrition, certainly for animals on a relatively high plane of nutrition. Peptides and amino acids arising from proteolysis are potential nutrients for the growth of rumen microorganisms, but they are also liable to be degraded to ammonia and lost from the rumen. Proteolytic activity occurs in all three main categories of rumen microorganisms. Bacteria are mainly responsible for dietary protein breakdown, while ciliate protozoa break down particulate feed protein of appropriate size and also bacterial protein. The key features of rumen proteolytic activity are that it varies greatly from animal to animal and from feed to feed. The predominant mechanism of peptide degradation is biphasic, via dipeptidyl aminopeptidases which cleave dipeptides from larger peptides followed by dipeptidase. Dipeptidyl aminopeptidase activity occurs only in Prevotella ruminicola among the common rumen microbial species. In contrast, dipeptidase, which cleaves the dipeptide products from dipeptidyl aminopeptidase, is present in many species, including $P$. ruminicola, and is particularly high in rumen protozoa. Deamination of amino acids is carried out by a combination of numerous lowactivity bacteria and protozoa and a much smaller number of high-activity species. Most ammonia production is probably carried out by the low-activity species, which again include $P$. ruminicola, but proliferation of the high-activity species may be a problem on certain diets.

The microbiology of protein breakdown in the rumen is of interest because it deals with one of the major inefficiencies of ruminant nutrition, namely the too-rapid conversion of protein to ammonia in the rumen and the subsequent loss of that ammonia by absorption across the rumen wall and excretion as urea (Leng and Nolan, 1984; Wallace and Cotta, 1988; Wallace, 1994). This review describes the microorganisms involved at different stages of the breakdown process and assesses the relative importance of different species in the light of population densities and the properties of the mixed rumen population.

\section{Proteolytic ruminal microorganisms}

The mixed rumen microbial population has a proteolytic activity that is only moderate compared with other proteolytic microorganisms and the host's own gastric and pancreatic secretions, but the length of time that feed material is retained in the rumen means that this activity is able to break down a substantial proportion of most dietary proteins (Ørskov and McDonald, 1979; Broderick et al, 1991). Many strains and species of rumen ciliate protozoa, bacteria and anaerobic fungi have been found to be proteolytic, and they contain a variety of different types of proteolytic enzymes (table I) (Wallace and Cotta, 1988; Wallace, 1994).

The predominant species of proteolytic bacterium found in the rumen of most animals is Prevotella (formerly Bacteroides) ruminicola, which has been identified as proteolytic in many studies (Blackburn and Hobson, 1962; Fulghum and Moore, 1963; Hazlewood and Nugent, 1978; Wallace and Brammall, 1985) and which can comprise more than $60 \%$ of the flora under some circumstances (Van Gylswyk, 1990). Its cell-associated, mainly cysteine protease activity, is fairly typical of the rumen bacterial population as a whole. Some animals possess Butyrivibrio fibrisolvens as the most prevalent proteolytic isolate (Blackburn and Hobson, 1962; Fulghum and Moore, 1963; Hazlewood et al, 1983; Wallace and Brammall 1985). B. fibrisolvens, which has a higher specific activity than most other species (Wallace and Brammall, 1985), appeared to be present when the dietary protein was more resistant to degradation (Wallace et al, 1987). its extracellular serine protease activity 


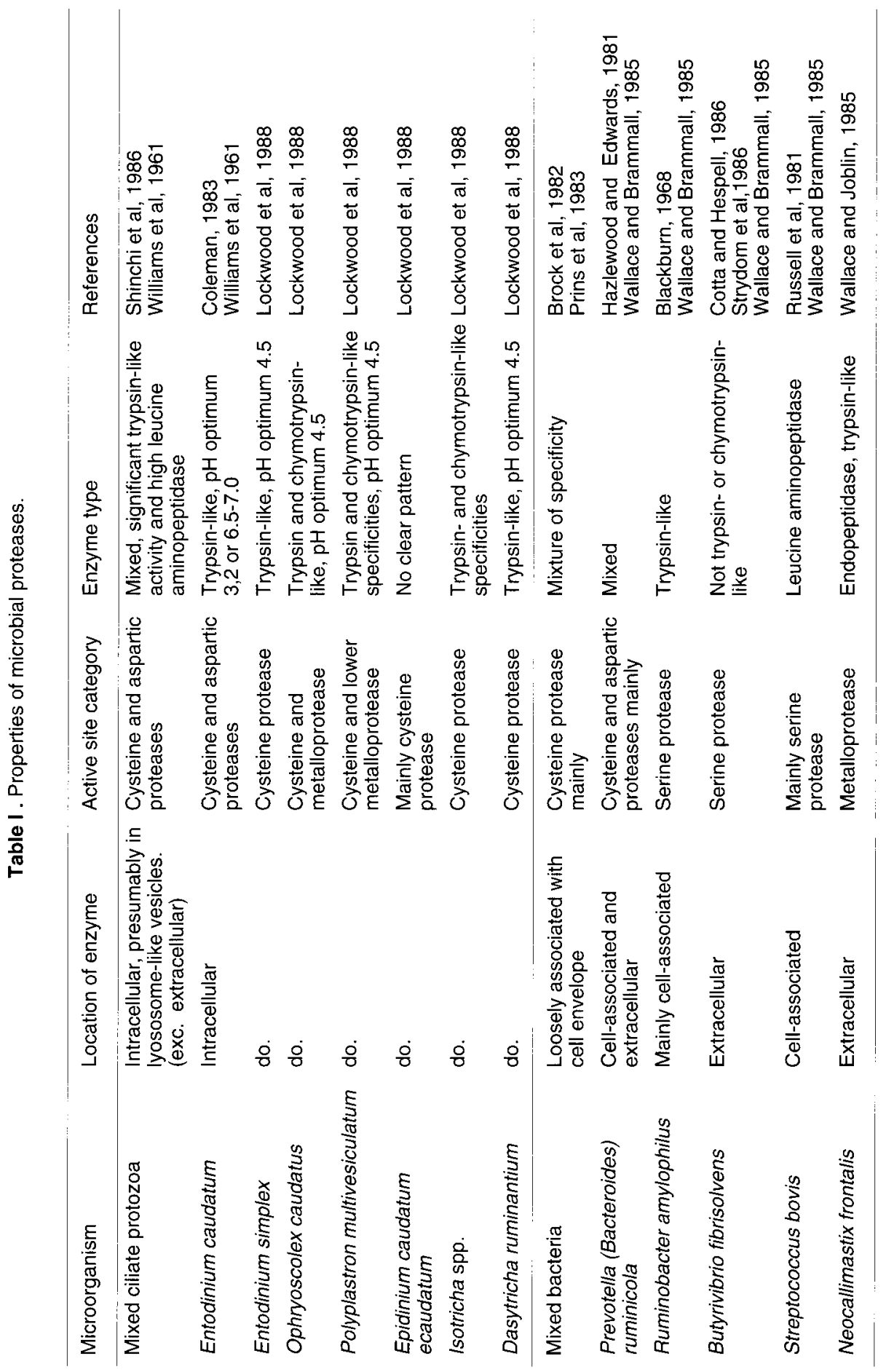


(Wallace and Brammall, 1985; Cotta and Hespell, 1986; Strydom et al, 1986) is not typical of in vivo activity.

Rumen ciliate protozoa exhibit a variety of protease activities, the most important of which are cysteine and aspartic proteases (Forsberg et al, 1984) that have a mixture of specificities with a significant trypsin-like activity (Prins et al, 1983; Forsberg et al, 1984). An Isotricha sp. had a protease profile on gel electrophoresis that was quite different to the profile of Dasytricha ruminantium, and representatives of four different entodiniomorphid genera also had different protease patterns (Lockwood et al, 1988). Extracellular extracts of rumen ciliates were reported to have a higher activity than intracellular extracts (Shinchi et al, 1986), but although these enzymes have been characterised biochemically (Shinchi and Kandatsu, 1983; Shinchi et al, 1986), their relevance to the mixed ecosystem has not been established.

Protozoa do not hydrolyse soluble protein as readily as do the bacteria. In the studies of Ushida et al $(1986,1991)$, defaunation resulted in a higher activity of rumen fluid towards soluble protein, which was believed to be caused by increased numbers of more active bacteria. A similar trend was seen with sheep which had been ciliate-free from birth (Wallace et al, 1987). However, protozoa ingest protein particles, either in the form of feed particles or bacteria, and they may be of great significance in diets containing particles of the correct dimensions.

Reports of proteolytic activity associated with rumen anaerobic fungi are conflicting. Whereas Neocallimastix frontalis had a high specific activity metalloprotease (Wallace and Joblin, 1985), most other fungal isolates had little proteolytic activity, although aminopeptidase was present in all species (Michel et al, 1993). Experiments with gnotobiotic lambs indicate that fungi play a minor role in proteolysis in vivo (Bonnemoy et al, 1993).

Proteolytic activity and the microbial species responsible for that activity are heavily diet-dependent (Nugent and Mangan, 1981; Siddons and Paradine, 1981; Hazlewood et al, 1983). However, perhaps the most remarkable feature of proteolysis is its inherent variability : different animals on the same or similar diets and housed together had completely different patterns of proteolytic enzymes in poly- acrylamide gels (Wallace and Cotta, 1988). Rational manipulation of ruminal proteolysis by altering the proteolytic population therefore appears only a distant possibility.

\section{Peptidolytic rumen microorganisms}

Peptide breakdown to amino acids must occur for the amino acids to be incorporated into microbial protein, and when there is sufficient energy available to fuel biosynthesis, amino acids will be incorporated and peptide breakdown would not be considered to be a major inefficiency in fermentation. However, when energy is unavailable, or when the rate of peptide breakdown exceeds the rate at which it can be assimilated, peptide catabolism leads to excessive ammonia production and poor $\mathrm{N}$ retention.

The great majority of peptidase activity in rumen fluid is aminopeptidase (Wallace et al, 1990a). It is characterised by dipeptides rather than single amino acids being cleaved from the peptide chain (table II) (Wallace et al, 1990a, 1993). Enzymes of this nature are classified as dipeptidyl aminopeptidases (Webb, 1992). The main mechanism of hydrolysis in intact rumen microorganisms appeared, from the hydrolysis of diagnostic synthetic substrates, to be dipeptidyl aminopeptidase type I (DAP-1) (Wallace and McKain, 1989), although other activities were also apparent. This pattern differs from that obtained with sonicated bacteria, which indicated among others a strong X-Ala-p-nitroanilide arylamidase (AlaDAP) activity (table II). The dipeptides released as a result of DAP activity are then broken down by separate dipeptidase activity. Ruminal peptide breakdown is therefore a two-stage process.

It was established by comparing the specific activities of mixed rumen protozoa and mixed bacteria prepared from rumen fluid that bacteria were mainly responsible for the breakdown of larger peptides (Newbold et al, 1989; Wallace et al, 1990c). When pure cultures of the most common rumen bacteria were screened for dipeptidyl aminopeptidase activity, remarkably the only common bacterial species that possessed DAP-1 and had high Ala-DAP activity was $P$. ruminicola (table III) (Wallace and McKain, 1991). Selective isolation, using fluorogenic DAP-1 substrate confirmed this unusual finding. $P$. ruminicola, 
Table II. Aminopeptidase activities of sonicated rumen bacteria ${ }^{1}$.

\begin{tabular}{|c|c|}
\hline Substrate & $\begin{array}{l}\text { Rate of } p \text {-nitroaniline release } \\
\qquad\left(\mu \mathrm{mol} \mathrm{ml}-1 \mathrm{~h}^{-1}\right)\end{array}$ \\
\hline Ala2-pNA & 0.85 \\
\hline ValAla-pNA & 0.50 \\
\hline GlyPro-pNA & 0.38 \\
\hline GlyArg-pNA & 0.13 \\
\hline Pro-pNA & 0.12 \\
\hline Lys-pNA & 0.02 \\
\hline Ala-, Arg-, Asp-, Gly-, Leu-, Met-, Tyr-, Val-pNA & $<0.01$ \\
\hline
\end{tabular}

1Author's unpublished results, expressed per $\mathrm{ml}$ of original rumen fluid.

Table III. Dipeptidylaminopeptidase and dipeptidase activities in rumen microorganisms.

\begin{tabular}{|c|c|c|c|}
\hline \multirow[b]{2}{*}{ Species } & \\
\hline & GlyArg- MNA ${ }^{1}$ & Ala2-pNA ${ }^{2}$ & $\mathrm{Ala}^{3}$ \\
\hline Mixed rumen microorganisms & 5.0 & 1.9 & $0.7-2.8$ \\
\hline Mixed protozoa & ND & ND & 7.5 \\
\hline Dasytricha ruminantium & ND & ND & 35.7 \\
\hline Entodinium spp. & ND & ND & 46.4 \\
\hline Isotricha spp. & ND & ND & 15.1 \\
\hline Mixed bacteria & ND & 3.9 & 2.8 \\
\hline Anaerovibrio lipolytica & 0 & 0 & 0 \\
\hline Butyrivibrio fibrisolvens & 0 & 3.7 & 1.6 \\
\hline Eubacterium ruminantium & 0.1 & 0.7 & 1.3 \\
\hline Fibrobacter succinogenes & 0 & 0.3 & 12.7 \\
\hline Lachnospira multipara & 0 & 1.1 & 3.9 \\
\hline Megasphaera elsdenii & 0 & 0 & 16.5 \\
\hline Mitsuokella multiacidus & 0 & 0 & 2.2 \\
\hline Peptostreptococcus anaerobius & 0 & ND & ND \\
\hline Prevotella ruminicola & $2.5-36.2$ & $11.3-31.5$ & $3.2-25.6$ \\
\hline Ruminobacter amylophilus & 0.3 & 0 & 3.9 \\
\hline Ruminococcus albus & 0 & 0 & 0.1 \\
\hline Ruminococcus flavefaciens & 0 & 0 & 2.2 \\
\hline Selenomonas ruminantium & 0 & ND & 4.2 \\
\hline Streptococcus bovis & 0 & 4.1 & 2.5 \\
\hline Veillonella parvula & 0 & 0 & 0 \\
\hline
\end{tabular}

Rate of peptide hydrolysis by whole cells (nmol min $^{-1} \mathrm{mg}^{2}$ protein ${ }^{-1}$ ) 
like the mixed rumen population, had low aminopeptidase activity against amino acyl-pnitroanilide substrates but high activity against dipeptidyl-p-nitroanilide substrates; it also cleaved dipeptides from longer peptides as the first step in peptide hydrolysis (Wallace et al, 1993). Once again, the pattern of peptide breakdown would be expected to change with diet and its influence on numbers of $P$. ruminicola. If organisms such as $S$. bovis were to prevail, their leucine aminopeptidase activity would predominate and amino acids might be cleaved singly from the peptide chain rather in pairs (Russell and Robinson, 1984; Wallace and Brammall, 1985). However, in the sheep that have been examined at the Rowett Research Institute, there is no doubt that, in total contrast to proteolysis being carried out by a large and variable number of species, oligopeptides are cleaved predominantly by only one bacterial species, namely $P$. ruminicola.

In contrast to the limited occurrence of dipeptidyl aminopeptidase, many species of protozoa and bacteria have dipeptidase activity (table III). Among the bacteria, $P$. ruminicola had activity against a wide range of dipeptides, while $M$. elsdenii also had a high activity (Wallace and McKain, 1991). The $P$. ruminicola dipeptidase is a Mn-metalloprotease (Wallace et al, 1995).

\section{Rumen microorganisms forming ammonia from amino acids}

Many experiments were done in the 1950s, 60 s and 70 s to determine the metabolism and fate of amino acids in mixed rumen contents (Blackburn, 1965; Allison, 1970; Chalupa, 1976; Broderick and Balthrop, 1979). As well as being nutritionally wasteful, the products of amino acid breakdown may be toxic to the animal (Carlson et al, 1972; Onodera, 1993). Most recently the main issue has been the nature of the microbial population that is primarily responsible for ammonia production in vivo. For many years, it had been assumed that deamination was carried out by a large number of the main species of rumen bacteria that had been identified to produce ammonia from protein or protein hydrolysates (Bladen et al, 1961).

However, Russell and his colleagues at Cornell (Chen and Russell, 1988, 1989;
Russell et al, 1988, 1991) calculated that these bacteria did not have sufficient activity to account for observed rates of ammonia production by the mixed population in their cattle, and isolated a group of bacteria that were much less numerous than the others, but which possessed a specific activity of ammonia production which was an order of magnitude greater than that of the other species. Moreover, these bacteria, unlike the others, were highly sensitive to monensin, and since ammonia concentrations are lower when ruminants receive this dietary ionophore, it was deduced that they must be significant ammonia producers in vivo. The species isolated, Peptostreptococcus anaerobius, Clostridium sticklandii and Clostridium aminophilum (Paster et al, 1993), were atypical of the main ruminal species, although a large number of clostridia have been isolated from the rumen over the years (Stewart and Bryant, 1988). These bacteria, and also the mimosine degrader, Synergistes jonesii (Allison et al, 1992; McSweeney et al, 1993), did not ferment sugars but used amino acids as their main source of carbon and energy as well as as a nitrogen source. The dichotomy is, therefore, that amino acid deamination could be carried out predominantly numerically abundant bacteria each having low activity, or by relatively few species each with exceptionally high deaminative activity (Figure 1).

Until now, there have been no reports of high-activity bacteria similar to those isolated at Cornell having been isolated elsewhere. Recently, however, cattle and sheep at the Rowett Research Institute were sampled and the numbers of monensin-sensitive Trypticase degraders enumerated (Eschenlauer, 1994). Their viable count indicated that bacteria capable of growth on Trypticase alone were present at $0.7 \%$ of the total bacterial population, numbers similar to those reported by Yang and Russell (1993), and like the Cornell bacteria they were monensin-sensitive. However, most of these bacteria, unlike the Cornell isolates, fermented sugars. Furthermore, ammonia production in the rumen fluid from which they were derived was much lower than in the Cornell studies and therefore it was not necessary to invoke the intervention of high-activity bacteria. This may be true in other studies too where the rates of ammonia production are relatively low.

Ammonia production in the rumen fluid of 


\begin{tabular}{|c|c|}
\hline $\begin{array}{l}\text { High numbers } \\
\text { Low activity }\end{array}$ & $\begin{array}{l}\text { Low numbers } \\
\text { High activity }\end{array}$ \\
\hline Butyrivibrio fibrisolvens & Clostridium aminophilum \\
\hline Megasphaera elsdenii & Clostridium sticklandii \\
\hline Prevotella ruminicola & Peptostreptococcus anaerobius \\
\hline Selenomonas ruminantium & \\
\hline Streptococcus bovis & \\
\hline$>10^{9} \mathrm{ml}^{-1}$ & $10^{9} \mathrm{ml}^{-1}$ \\
\hline $10-20 \mathrm{nmol} \mathrm{NH}_{3} \min ^{-1}$ (mg protein) $)^{-1}$ & $300 \mathrm{nmol} \mathrm{NH}_{3} \min ^{-1}$ (mg protein) $)^{-1}$ \\
\hline Mainly monensin-resistant & Monensin-sensitive \\
\hline
\end{tabular}

Figure 1. A summary of the properties of ammonia-producing bacteria from the rumen.

these same animals was inhibited less than half by monensin, similar to the inhibitions observed in similar sheep with monensin and tetronasin (Wallace et al, 1990b). Yang and Russell (1993) also found that the rate of ammonia production from casein was inhibited less than half by extremely high concentrations of monensin ( $5 \mathrm{mM}$ cf. a likely concentration in vivo of $4 \mathrm{mM}$ ) (Wallace et al, 1981), although the effect was greater for lower rates of ammonia production. Decreased ammonia production with ionophores may indeed be due partly to elimination of high-activity bacteria, but it should also be recognised that the influence of ionophores extends beyond those species whose growth is inhibited and are generally recognised to be 'monensinsensitive'. The deaminative activity of $P$. ruminicola and Ruminobacter amylophilus, bacteria that can grow when ionophores are present, was greatly diminished when they were grown with ionophores in the medium (Newbold et al, 1990). Furthermore, the deamination of reduced amino acids will be affected indirectly by monensin, via decreased hydrogenase activity (Russell and Martin, 1984; Hino and Russell, 1985). The long-term effects of ionophores on ammonia production in vivo are therefore due partly to an effect on the residual, apparently ionophore-insensitive species as well as to the suppression of the high-activity species.

It may be concluded that amino acid deamination is carried out by two distinct bacterial populations of either low-activity/high numbers or high-activity/low numbers characteristics. The former population is probably of greater significance under most circumstances. However, it is extremely important to suppress the proliferation of the high-activity species since the presence of only a small population of these organisms could have a major impact on the efficiency of $\mathrm{N}$ retention by the animal.

\section{Conclusions}

The pattern of conversion of protein to ammonia is rather like a funnel. Many species participate in the initial proteolytic cleavage. The resultant oligopeptides then funnel down to to be hydrolysed largely by one species, $P$. ruminicola. Thereafter, the products diverge as many species of bacteria and protozoa break down dipeptides and amino acids. Regulation of the process has thus far concentrated on the first or last steps. Since the constriction in the flow is at $P$. ruminicola, it seems that the peptidases of this organism deserve detailed study.

\section{Literature cited}

Allison MJ (1970) Nitrogen metabolism of ruminal micro-organisms. In: Physiology of Digestion and Metabolism in the Ruminant (Phillipson AT, ed) Oriel Press Ltd, Newcastle, 456-472

Allison MJ, Mayberry WR, McSweeney CS, Stahl DA (1992) Synergistes jonesii, gen. nov., sp. nov., a rumen bacterium that degrades toxic pyridinediols. System Appl Microbiol 15, 522-529

Blackburn TH (1965) Nitrogen metabolism in the rumen. In: Physiology of Digestion in the Ruminant (Dougherty RW, Allen RS, Burroughs W, Jacobson NL, McGilliard AD, eds) Oriel Press, Newcastle-upon-Tyne, 322-334

Blackburn TH (1968) The protease liberated from Bacteroides amylophilus strain $\mathrm{H} 18$ by mechanised disintegration. $J$ Gen Microbiol 53 , 37-51

Bladen HA, Bryant MD, Doetsch RN (1961) A study of bacterial species from the rumen which produce 
ammonia from protein hydrolyzate. Appl Microbiol 9, 175-180

Bonnemoy F, Fonty G, Michel V, Gouet Ph (1993) Effect of anaerobic fungi on the ruminal proteolysis in gnotobiotic lambs. Reprod Nutr Develop 33, 551-555

Brock FM, Forsberg CW, Buchanan-Smith JG (1982) Proteolytic activity of rumen microorganisms and effects of proteinase inhibition. App/ Environ Microbiol 44, 561-569

Broderick GA, Balthrop JE (1979) Chemical inhibition of amino acid deamination by ruminal microbes in vitro. J Anim Sci 49, 1101-1111

Broderick GA, Wallace RJ, Orskov ER (1991) Control of rate and extent of protein degradation. In: Physiological Aspects of Digestion and Metabolism in Ruminants (Tsuda T, Sasaki $\mathrm{Y}$, Kawashima R, eds) Academic Press, London, 541-592

Carlson JR, Yokoyama MT, Bickinson EO (1972) Induction of pulmonary edema and emphysema in cattle and goats with 3-methylindole. Science $176,289-299$

Chalupa W (1976) Degradation of amino acids by the mixed rumen microbial population. J Anim Sci 43 , 828-834

Chen G, Russell JB (1988) Fermentation of peptides and amino acids by a monensin-sensitive ruminal Peptostreptococcus. Appl Environ Microbiol 54, 2742-2749

Chen G, Russell JB (1989) More monensin-sensitive, ammonia-producing bacteria from the rumen. Appl Environ Microbiol 55, 1052-1057

Coleman GS (1983) Hydrolysis fraction I leaf protein and casein by rumen entodiniomorphid protozoa. App/ Environ Microbiol 55, 1052-1057

Cotta MA, Hespelt RB (1986) Proteolytic activity of the ruminal bacterium Butyrivibrio fibrisolvens. Appl Environ Microbiol 52, 51-58

Eschenlauer S (1994) Les bacteries fermentrices obligatoires des peptides et acides amines du rumen. Universite d'Auvergne, Clermont-Ferrand,

Forsberg CW, Lovelock LKA, Krumholz L, BuchananSmith JG (1984) Protease activities of rumen protozoa. Appl Environ Microbio/ 47, 101-110

Fulghum RS, Moore WEC (1963) Isolation, enumeration, and characteristics of proteolytic ruminal bacteria. J Bact $85,808-815$

Hazlewood GP, Edwards R (1981) Proteolytic activities of a rumen bacterium, Bacteroides ruminicola R8/4. J Gen Microbiol 125, 11-15

Hazlewood GP, Nugent JHA (1978) Leaf fraction 1 protein as a nitrogen source for the growth of a proteolytic rumen bacterium. I Gen Microbiol 106, 369-37

Hazlewood GP, Orpin CG, Greenwood Y, Black ME (1983) Isolation of proteolytic rumen bacteria by use of selective medium containing leaf fraction 1 protein (ribulose bis phosphate carboxylase). Appl Environ Microbiol 45, 1780-1784

Hino T, Russell JB (1985) Effect of reducingequivalent disposal and NADH/NAD on deamination of amino acids by intact rumen microorganisms and their cell extracts. Appl Environ Microbiol 50, 1368-1374

Leng RA, Nolan JV (1984) Nitrogen metabolism in the rumen. J Dairy Sci 67, 1072-1089

Lockwood BC, Coombs GH, Williams AG (1988) Proteinase activity in rumen ciliate protozoa. $J$ Gen Microbiol 134, 2605-2614

McKain N, Wallace RJ, Watt ND (1992) Selective isolation of bacteria with dipeptidyl aminopeptidase type I activity from the sheep rumen. FEMS Microbiol Lett 95, 196-174

McSweeney CS, Allison MJ, Mackie RI (1993) Amino acid utilization by the ruminal bacterium Synergistes jonesii. Arch Microbiol 159, 131-135

Michel V, Fonty G, Millet L, Bonnemoy F, Gouet Ph (1993) In vitro study of the proteolytic activity of rumen anaerobic fungi. FEMS Microbiol Lett 110 , 5-10

Newbold CJ, McKain N, Wallace RJ (1989) The role of protozoa in ruminal peptide metabolism. in: Biochemistry and Molecular Biology of Anaerobic Protozoa (Lloyd D, Coombs GH. Paget TAP, eds) Harwood Academic Publishers, London, 42 55

Newbold CJ, Wallace RJ, McKain N (1990) Effect of the ionophore tetronasin, on nitrogen metabolism of rumen microorganisms in vitro. J Anim Sci 68, 1103-1109

Nugent JHA, Mangan JL (1981) Characteristics of the rumen proteolysis of fraction I (18S) leaf protein from lucerne (Medicago sativa $\mathrm{L}$ ). Br J Nutr 46 , 39-58

Onodera R (1993) Methionine and lysine metabolisn in the rumen and the possible effects of their metabolites on the nutrition and physiology of ruminants. Amino Acids 5, 217-232

Orskov ER, McDonald I (1979) The estimation of protein degradability in the rumen from incubation measurements weighted according to rate of passage. J Agric Sci Camb 92, 499-503

Paster BJ, Russell JB, Yang CMJ, Chow JM, Woese CR, Tanner R (1993) Phylogeny of the ammoniaproducing ruminal bacteria Peptostreptococcus anaerobius, Clostridium sticklandii and Clostridium aminophilum sp.nov. Int J System Bacterio/ 43, 107-110

Prins RA, Van Rheenen DL, Van't Dlooster AT (1983) Characterisation of microbial proteolytic enzymes in the rumen. Ant van Leeuw 49, 585-595

Russell JB, Martin SA (1984) Effects of various methane inhibitors on the fermentation of amino acids by mixed rumen microorganisms in vitro. $J$ Anim Sci59, 1329-1338 
Russell JB, Robinson PH (1984) Composition and characteristics of strains of Streptococcus bovis. $J$ Dairy Sci67, 1525-1531

Russell JB, Bottje WG, Cotta MA (1981) Degradation of protein by mixed cultures of rumen bacteria: identification of Streptococcus bovis as an actively proteolytic rumen bacteria. $J$ Anim Sci 53, 242-252

Russell JB, Strobel HJ, Chen G (1988) Enrichment and isolation of a ruminal bacterium with a very high specific activity of ammonia production. Appl Environ Microbiol 54, 872-877

Russell JB, Onodera R, Hino T (1991) Ruminal protein fermentation, new perspectives on previous contradictions. In: Physiological aspects of Digestion and Metabolism in Ruminants (Tsuda T, Sasaki Y, Kawashima R, eds) Academic Press, Tokyo, 681-697

Shinchi S, Itoh T, Abe M, Kandatsu M (1986) Effect of rumen ciliate protozoa on the proteolytic activity of cell free rumen fluid. Jap J Zootech Sci 57, 8996

Shinchi S, Kandatsu M (1983) On some properties of extracellular proteolytic activity of rumen ciliate protozoa. Jap J Zootech Sci 54, 290-296

Siddons RC, Paradine J (1981) Effect of diet on protein degrading activity in the sheep rumen. $J$ Sci Food Agric 32, 973-981

Stewart CS, Bryant MP (1988) The rumen bacteria In: The Rumen Microbial Ecosystem (Hobson PN, ed) Elsevier Applied Science, London, 21-75

Strydom E, Mackie RI, Woods DR (1986) Detection and characterization of extracellular proteases in Butyrivibrio fibrisolvens $\mathrm{H} 17 \mathrm{C}$. Appl Microbiol Biotechnol

Ushida K, Jouany JP, Demeyer DI (1991) Effects of presence or absence of rumen protozoa on the efficiency of urilization of concentrate and fibrous feeds. In: Physiological aspects of Digestion and Metabolism in Ruminants (Tsuda T, Sasaki $Y$, Kawashima R, eds) Academic Press, Tokyo, $625-654$

Ushida K, Jouany JP, Thivend P (1986) Role of rumen protozoa in nitrogen digestion in sheep given two isonitrogenous diets. $B r J$ Nutr 56 , $407-419$

Van Gylswyk NO (1990) Enumeration and presumptive identification of some functional groups of bacteria in the rumen of dairy cows fed grass silage-based diets. FEMS Microbiol Ecol $73,243-254$

Wallace RJ (1994) Amino acid and protein synthesis, turnover, and breakdown by rumen microorganisms. In: Protein Metabolism in Ruminants (Asplund JM, ed) CRC Press, Boca Raton, Florida, 71-111

Wallace RJ, Brammall ML (1985) The role of different species of rumen bacteria in the hydrolysis of protein in the rumen. J Gen Microbiol 131 , 821-832

Wallace RJ, Cotta MA (1988) Metabolism of nitrogencontaining compounds. In: The Rumen Microbial Ecosystem (Hobson PN, ed) Elsevier Applied Science, London, 217-250

Wallace RJ, Joblin KN (1985) Proteolytic activity of a rumen anaerobic fungus. FEMS Microbiol Lett 29, 119-125

Wallace RJ, McKain N (1989) Analysis of peptide metabolism by ruminal microorganisms. Appl Environ Microbiol 55, 2372-2376

Wallace RJ, McKain N (1991) A survey of peptidase activity in rumen bacteria. J Gen Microbiol 137, 2259-2264

Wallace RJ, Czerkawski JW, Breckenridge G (1981) Effect of monensin on the fermentation of basal rations in the Rumen Simulation Technique (Rusitec). Br J Nutr 46, 131-148

Wallace RJ, Broderick GA, Brammall ML (1987) Microbial protein and peptide metabolism in rumen fluid from faunated and ciliate-free sheep. Br J Nutr 58, 87-93

Wallace RJ, Newbold CJ, McKain N (1990a) Patterns of peptide metabolism by rumen microorganisms. In: The Rumen Ecosystem. The Microbial Metabolism and its Control (Hoshino S, Onodera $\mathrm{R}$, Minato $\mathrm{H}$, Itabashi $\mathrm{H}$, eds) Tokyo, Japan Scientific Societies Press, 43-50

Wallace RJ, Newbold CJ, McKain N (1990b) Influence of ionophores and energy inhibitors on peptide metabolism by rumen bacteria. J Agric Sci, Camb $115,285-290$

Wallace RJ, McKain N, Newbold CJ (1990c) Metabolism of small peptides in rumen fluid. Accumulation of intermediates during hydrolysis of alanine oligomers, and comparison of peptidolytic Activities of bacteria and protozoa. $J$ Sci Food Agric 50, 191-199

Wallace RJ, Mckain N, Broderick GA (1993) A comparison of the breakdown of pure peptides by Bacteroides ruminicola and mixed microorganisms from the sheep rumen. Current Microbiology 26, 333-336

Wallace RJ, Kopecny J, Broderick GA, Walker ND, Sichao L, Newbold CJ, McKain N (1995) Cleavage of dipeptides by Prevotella (Bacteroides) ruminicola. Anaerobe (in press)

Webb EC (1992) Enzyme Nomenclature 1992. Academic Press, London, $863 p$

Williams PP, Davis RE, Doetsch RN, Gutierrez J (1961) Physiological studies of the rumen ciliate Ophryoscolex caudatus Eberlein. Appl Microbiol 9, 405-409

Yang CMJ, Russell JB (1993) Effect of monensin on the specific activity of ammonia production by ruminal bacteria and disappearance of amino nitrogen from the rumen. Appl Environ Microbiol $59,3250-325$ 